\title{
Adaptation mechanism and tolerance of Rhodopseudomonas palustris PSB-S under pyrazosulfuron-ethyl stress
}

\author{
Xiang-Wen Luo ${ }^{1,2+}$, De-Yang Zhang ${ }^{1,2+}$, Teng-Hui Zhu², Xu-Guo Zhou ${ }^{3}$, Jing Peng ${ }^{1,2}$, Song-Bai Zhang ${ }^{1 *}$ (D) and \\ Yong Liu $^{1,2^{*}}$
}

\begin{abstract}
Background: Pyrazosulfuron-ethyl is a long lasting herbicide in the agro-ecosystem and its residue is toxic to crops and other non-target organisms. A better understanding of molecular basis in pyrazosulfuron-ethyl tolerant organisms will shed light on the adaptive mechanisms to this herbicide.

Results: Pyrazosulfuron-ethyl inhibited biomass production in Rhodopseudomonas palustris PSB-S, altered cell morphology, suppressed flagella formation, and reduced pigment biosynthesis through significant suppression of carotenoids biosynthesis. A total of 1127 protein spots were detected in the two-dimensional gel electrophoresis. Among them, 72 spots representing 56 different proteins were found to be differently expressed using MALDITOF/TOF-MS, including 26 up- and 30 down-regulated proteins in the pyrazosulfuron-ethyl-treated PSB-S cells. The up-regulated proteins were involved predominantly in oxidative stress or energy generation pathways, while most of the down-regulated proteins were involved in the biomass biosynthesis pathway. The protein expression profiles suggested that the elongation factor G, cell division protein FtsZ, and proteins associated with the ABC transporters were crucial for $R$. palustris PSB-S tolerance against pyrazosulfuron-ethyl.

Conclusion: Up-regulated proteins, including elongation factor G, cell division FtsZ, ATP synthase, and superoxide dismutase, and down-regulated proteins, including ALS III and ABC transporters, as well as some unknown proteins might play roles in $R$. palustris PSB-S adaptation to pyrazosulfuron-ethyl induced stresses. Functional validations of these candidate proteins should help to develope transgenic crops resistant to pyrazosulfuron-ethyl.
\end{abstract}

Keywords: Pyrazosulfuron-ethyl, Rhodopseudomonas palustris PSB-S, Cytology, Proteomic, Adaption mechanism

\section{Background}

Pyrazosulfuron-ethyl, one of the acetolactate synthase (ALS; EC4.1.3.18) inhibiting herbicides in the sulphonylurea family [1], has been widely used to control weed growth in commercial cereal, soybean, and vegetable fields. Due to its high herbicidal activity $\left(2-100 \mathrm{~g} / \mathrm{hm}^{2}\right)$, specific plant selectivity, very low aquatic life toxicity, and low bio-concentration in the non-targeted organisms [2, 3], utilization of pyrazosulfuron-ethyl in China

\footnotetext{
* Correspondence: zsongb@hotmail.com; haoasliu@163.com

${ }^{+}$Xiang-Wen Luo and De-Yang Zhang contributed equally to this work.

'Key laboratory of pest management of horticultural crop of Hunan province, Hunan Plant Protection Institute, Hunan Academy of Agricultural Science, No 726 Second Yuanda Road, Furong District, Changsha 410125, Hunan province, People's Republic of China

Full list of author information is available at the end of the article
}

has been increased significantly to reduce the labor intensity and increase the input-output ratio [4]. However, pyrazosulfuron-ethyl is also known to be a long lasting herbicide in the agro-ecosystem $\left(t_{1 / 2}>74.6 \mathrm{~d}\right.$ for pyrazosulfuron-ethyl in soil with half maximum water holding capacity) [5], and its residue is toxic to certain food crops and others organisms [6, 7]. This sensitivity limited the potential application of pyrazosulfuron-ethyl in many important food crops.

Chemicals of sulfonylurea family could change the cell structure of mouse pancreatic $\beta$-cells and pancreatic islet cells $[8,9]$. Sulphonylurea herbicide tribenuron-methyl could change anther cell morphology and resulted in male sterility of rapeseed (Brassica napus) and Arabidopsis [10]. The plastid 
ultrastructure was abnormal in pollen mother cells and tapetal cells in male sterility of Brassica napus L treated by sulphonylurea herbicide monosulfuron ester sodium [11]. Pyrazosulfuron-ethyl also alter the cell structure of degrading microbacteria [12]. It is rational to deduce pyrazosulfuron-ethyl alter the cell morphology of organism, which should be one of the vital adaptation against pyrazosulfuron-ethyl.

To counteract the toxicity of pyrazosulfuron-ethyl residual in the agro-ecosystem, crops need to be improved to show better tolerance or resistance to pyrazosulfuron-ethyl treatment though various adaptions and/or modifications $[13,14]$. To date, only a few genes, including ALS genes and cytochrome P-450 gene, were cloned and characterized to be resistant genes against herbicides in the sulphonylurea family [15-17]. However, successful incorporation of these resistant genes into commercial crops still needs time and effort.

Proteomics is a quick and high throughput technology for identifications of proteins in cells or in tissues grown under various conditions. One of the protomic technologies utilizes two-dimensional gel electrophoresis followed by protein identifications through mass spectrometry. It has been employed by many research groups to uncover the strategies used by plants to combat stresses caused by herbicide applications [18, 19]. To date, this technology has not been used to elucidate the molecular mechanisms controlling the resistance in bacteria to sulphonylurea herbicides, despite of the current knowledge on toxicology of decreasing diversity of soil microbial communities and inhibiting population growth tests to Azospirillum lipoferum and Bacillus megaterium against sulphonylurea herbicides [20].

Bacterial strains belong to genus Rhodopseudomonas are known have excellent capacities of hydrogen production, carbon dioxide fixation and organic compounds degradation [21]. Moreover, $R$. sp. S9-1 was documented with high concentration pyrazosulfuron-ethyl tolerance (upto $800 \mu \mathrm{g} / \mathrm{ml}$ ), which probably contributed to its mutant ALS gene [22]. However, the adaption mechanism of bacterial strains of Rhodopseudomonas under pyrazosulfuron-ethyl stress remained unclear. $R$. palustris PSB-S was isolated and characterized to be resistant to pyrazosulfuron-ethyl at a concentration of $200 \mu \mathrm{g} / \mathrm{mL}$ [23]. In this study, we conducted cytological and protein expression studies using pyrazosulfuron-ethyl treated and non-treated PSB-S cells through electron microscopy and 2-dimensional gel-based comparative proteome. We consider that the results presented in this paper may provide useful information or potential strategies to improve crop sensitivity to this herbicide through molecular manipulations.

\section{Methods}

Bacterial strain, culture conditions and growth media

Rhodopseumonas palustris PSB-S was identified previously (DDBJ/ENA/GenBank accession no. of draft genomic sequence: JHAA00000000) and stored at $-80^{\circ} \mathrm{C}$ till use.

Culture medium [24] used in this study contained 2.0 g Sodium L-malatate, $2.0 \mathrm{~g}$ Sodium glutamate, $1.0 \mathrm{mg}$

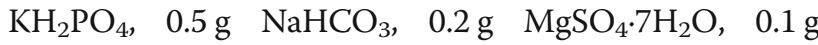
$\mathrm{CaCl}_{2} \cdot 2 \mathrm{H}_{2} \mathrm{O}, 2.0 \mathrm{mg} \mathrm{MnSO} \mathrm{M}_{4} \cdot \mathrm{H}_{2} \mathrm{O}, 0.5 \mathrm{mg} \mathrm{FeSO}_{4} \cdot 7 \mathrm{H}_{2} \mathrm{O}$, $0.5 \mathrm{mg} \mathrm{CoCl}{ }_{2} \cdot 2 \mathrm{H}_{2} \mathrm{O}$, and $0.5 \mathrm{~g}$ yeast extract in one liter deionized $\mathrm{H}_{2} \mathrm{O}$. For solid medium, $15 \mathrm{~g}$ technical grade agar was added to one liter liquid medium. After autoclaving, pyrazosulfuron-ethyl was added to the medium at specific concentrations as stated below.

Approximately $10^{9} \mathrm{cfu} / \mathrm{mL}$ cells were inoculated to a $120 \mathrm{ml}$ growth medium in $130 \mathrm{~mL}$ serum bottles with airproofed rubber plugs and the cultures were grown in a chamber illuminated at approximately $3000 \mathrm{~lx}$ and at $30 \pm 1{ }^{\circ} \mathrm{C}$. Growth of the cultures was determined by Spectrophotometry at $660 \mathrm{~nm}$.

\section{Scanning and transmission electron microscopy (SEM and TEM)}

Morphology of $R$. palustris PSB-S cells was determined by SEM. Briefly, freshly prepared and concentrated cell suspensions were fixed and dried before SEM using an JEXL-230 scanning electron microscope (Japan) as described previously [25].

To determine ultrastructural changes in the $R$. palustris PSB-S cell, cells were fixed and then embedded in LR White resin as described [25]. The specimens were sectioned with a Leica EM UC7 Ultramicrotome (Leica Microsystems, Germany). The sections (70 nm thick) were mounted on 600-mesh formvar-coated copper grids, and examined and photographed under a transmission electron microscope (JEM-1230, JEOL, Tokyo, Japan) as described [25].

\section{Quantification of photopigments in strain PSB-S cells}

Photopigments in strain PSB-S cells were extracted using a modified methanol/acetone extraction method [26]. The cells were collected by centrifuging, rinsed and resuspended in $\mathrm{ddH}_{2} \mathrm{O}$. Sonicated cell broth was extracted with methanol and acetone. The photopigment Carotenoid (Car) was then quantified by the Jassen formula, C $=(\mathrm{D} \cdot \mathrm{V} \cdot \mathrm{f} \times 10) / 2500[\mathrm{C}, \mathrm{Car}$ quantification $(\mathrm{mg}) ; \mathrm{V}$, total volume of extract buffer; f, dilution fold; D, photodensity of Car at the maximum absorption peak]. The photopigment bacteriochlorin (Bchl) was calculated by the Beer-Lambert-Bouguer law, C = D.V.F $/(\mathrm{a} \cdot \mathrm{L}) \times 10^{3}[\mathrm{a}$, extinction coefficient $(\mathrm{L} / \mathrm{g} \cdot \mathrm{cm}) ; \mathrm{L}$, optical distance $(\mathrm{cm})]$. Quantification of total photopigments was determined by addition of Car and Bchl. 


\section{Protein extraction}

Total protein was extracted from $R$. palustris PSB-S culture cells using a bacterial protein extraction kit (BigBlueInteractive, NY). Concentrations of total protein in extracts were estimated by the Bradford assay [27]. For each treatment, three protein extracts from three different flasks were prepared.

\section{Protein separation and quantification through 2D-DIGE electrophoresis}

The resulting total protein samples were rehydrated in the sample buffer [ $8 \mathrm{M}$ urea, $2 \mathrm{M}$ thiourea, $0.5 \% \mathrm{CHAPS}$, $40 \mathrm{mM}$ Tris-base, $0.02 \%$ bromophenol blue, $1.2 \%$ DTT, carrier ampholytes $0.52 \%(\mathrm{v} / \mathrm{v})$ Pharmalyte] and separated on non-linear $\mathrm{pH}$ 4-7 gradient immobiline DryStrips (17 cm-long) (GE Healthcare Bio-Sciences AB, Beijing). For the second dimension separation, strips were cup-loaded at the anodic side of $12 \%$ SDS-PAGE gels $(18 \times 20 \mathrm{~cm})$ after overnight rehydration at room temperature [28].

\section{Comparative analysis and protein identification}

Gels were stained with Coomassie blue and images of the gels (three gels per sample) were captured using the TyphoonTM 9410 scanner (GE Healthcare) after destaining [54]. Protein spot were quantified based on the digitized staining intensity within the spot boundaries and used for calculations of protein expressions. The normalized expression profile data were then used to statistically determine the expression changes of individual protein spots. Protein spots showing $t \leq 0.05$ by the Student- $T$ test were considered to be significantly differentially regulated.

The protein identification process was as previously reported [29]. The protein spots of interest were digested in-gel with bovine trypsin, extracted with $0.1 \%$ trifluoroacetic acid in $60 \%$ acetonitrile, and analyzed by mass spectrometry (4700 Proteomics Analyzer, ABI, CA) equipped with a pulsed $\mathrm{N}_{2}$ laser $(337 \mathrm{~nm})$. Calibrations were conducted using the standard peptides. All peptide mass fingerprint spectra were internally calibrated with the trypsin autolysis peaks, and all the known contaminants were excluded during the process. The measured tryptic peptide masses were used for a MASCOT (version 2.2) search at the nonredundant NCBI (NCBInr) database and Swissprot database. The peptide mass spectra searching parameters were set as: fragment mass tolerance: $\pm 0.1 \mathrm{Da}$, fragment mass/mass tolerance: $\pm 0.5 \mathrm{Da}$, variable modification: oxidation, and fixed modification of cysteine by carboxymethyl (carbamidomethylation, $\mathrm{C}$ ), and peptide missed cleavage: 1+. Proteins identified by MALDI-TOF/TOF-MS/MS with C.I. \% scores above 95\% were selected and considered as significant.

\section{Bioinformatics analysis}

The GO enrichment analysis was performed using the Blast2GO [30]. Metabolic pathways of the identified proteins were generated according to the KEGG database (http://www.genome.jp//kegg/). In addition, the deferentially expressed proteins were further analyzed using the Search Tool for the Retrieval of Interacting Genes/Proteins (STRING; http://string.embl.de/) to build a functional protein association network.

Total RNA preparation and quantitative RT-PCR (qRT-PCR) Total RNA from cells of $R$. palustris PSB-S was extracted using TRIzol $^{\odot}$ reagent as instructed (Invitrogen, Beijing). The quality of total RNA samples was assessed by agarose gel electrophoresis and the concentration of total RNA was estimated using a spectrophotometer. cDNA synthesis was performed using an M-MLV RTase cDNA synthesis kit (TranGen, Beijing). Quantitative PCR (qPCR) was performed using the TransStart Green qPCR SuperMix UDG (TranGen, Beijing). The qPCR reaction mixture $(20 \mu \mathrm{L})$ consisted of $0.5 \mu \mathrm{L}$ cDNA, $10 \mu \mathrm{L}$ UDG, F/R primer $(0.5 \mu \mathrm{L} /$ each $)$, and $8.5 \mu \mathrm{L} \mathrm{ddH}_{2} \mathrm{O}$. After $2 \mathrm{~min}$ incubation at $50{ }^{\circ} \mathrm{C}$, the reaction was set at $95^{\circ} \mathrm{C}$ for $10 \mathrm{~min}$ followed by 44 cycles of amplification $\left(95^{\circ} \mathrm{C}\right.$ for $5 \mathrm{~s}, 60^{\circ} \mathrm{C}$ for $15 \mathrm{~s}$ and $72^{\circ} \mathrm{C}$ for $10 \mathrm{~s}$ ). The last step reaction was carried out at $95^{\circ} \mathrm{C}$ for $15 \mathrm{~s}, 65^{\circ} \mathrm{C}$ for $5 \mathrm{~s}$ and $95^{\circ} \mathrm{C}$ for $5 \mathrm{~s}$. Expression level of ribulose 1,5-bisphosphate carboxylase/oxygenase (RubisCO) gene [19] was used as the internal control during the study. Relative expression of each gene was determined using the relative quantification $(\mathrm{ddCt})$ method and was based on three biological replicates. All the primers used for qRT-PCR are listed in Additional file 1: Table S2.

\section{Statistical analysis}

All the statistical analyses were performed using the Data Processing System (DPS, version 9.50) [31]. Values are showed as mean \pm standard deviation (SD). Samples showing $\rho<0.05$ were considered to be statistically significant different.

\section{Results \\ Pyrazosulfuron-ethyl inhibited the growth of $R$. palustris PSB-S}

The growth of strain PSB-S in PSB medium is shown in Fig. 1. The result of cultivation phase (day 3-11) indicated that the growth of strain PSB-S was significantly inhibited in growth medium containing $50 \mu \mathrm{g} / \mathrm{mL}$ pyrazosulfuron-ethyl, especially during in the exponential growth phase (i.e., day 3-7). The biomass of strain PSB-S cells grown in the PSB medium with $50 \mu \mathrm{g} / \mathrm{mL}$ 


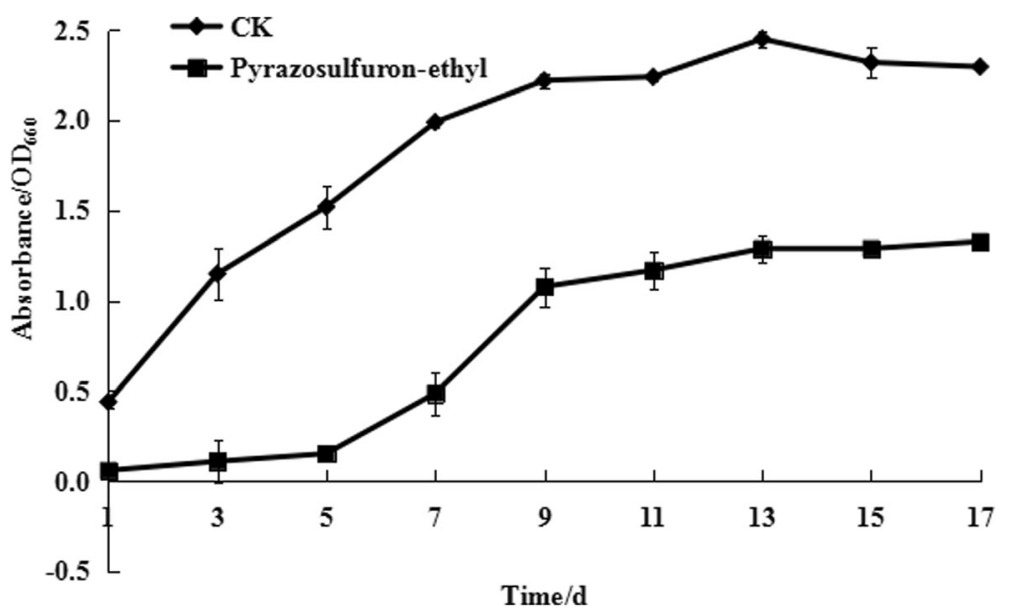

Time/d

Fig. 1 Effect of pyrazosulfuron-ethyl on R. palustris PSB-S growth. R. palustris PSB-S cultured in the PSB medium without $50 \mu \mathrm{g} / \mathrm{ml}$ pyrazosulfuronethyl was used as a control CK. Cell biomass was measured at 1 to 17 days post culturing

pyrazosulfuron-ethyl at day 3-7 were only about 15$36 \%$ of the cells grown in the PSB medium. During the equilibrium phase of cell growth (i.e., day 7-9), the growth of cells in the PSB medium with $50 \mu \mathrm{g} / \mathrm{mL}$ pyrazosulfuron-ethyl was increased rapidly. After day 9, the biomass of cells grown in the PSB medium with $50 \mu \mathrm{g} / \mathrm{mL}$ pyrazosulfuron-ethyl remained stable till day 11 but still significantly lower than the biomass of cells grown in the PSB medium without pyrazosulfuron-ethyl. Consequently, PSB-S cells were harvested at 7 days post culturing in the PSB medium with or without $50 \mu \mathrm{g} / \mathrm{ml}$ pyrazosulfuron-ethyl and used for further cytological and proteomic analyses.

\section{Effect of pyrazosulfuron-ethyl on $R$. palustris PSB-S cell morphology}

Surface morphology of pyrazosulfuron-ethyl-treated cells was examined by scanning electron microscopy and compared with that shown by the control cells (Fig. 2). Three distinct changes were observed on the surface of pyrazosulfuorn-ethyl-treated bacterial cells. First, pyrazosulfuorn-ethyl treatment inhibited polar flagella generation on bacterial cells. Second, the pyrazosulfuorn-ethyl-treated cells appeared significantly longer $(0.74 \pm 0.05 \mu \mathrm{m}$ in diameter and $2.16 \pm 0.38 \mu \mathrm{m}$ in length) than that of the control cells $(0.62 \pm 0.04 \mu \mathrm{m}$ in diameter and $3.38 \pm 0.54 \mu \mathrm{m}$ in length). Third, the pyrazosulfuorn-ethyl-treated cells often bent (see white arrows) and budded (see red arrows) while the control cells remained oval or short rod like shapes.

Intracellular alterations caused by pyrazosulfuron-ethyl treatment was studied by transmission electron microscopy (TEM). PSB-S cells treated with pyrazosulfuron-ethyl were fixed, embedded and sectioned for TEM. Under the electron microscope, electron dense areas were observed alongside the cell membrane (arrows, Fig. 3). These electron dense areas are known to accumulate lamella photo-pigments. Compared with the control cells, the electron dense areas in the pyrazosulfuron-ethyl-treated cells was smaller, suggesting inhibition of photo-pigments biosynthesis in these cells.

Two known photo-pigments, bacteriochlorin and carotenoid, were extracted from the pyrazosulfuron-ethyl-treated or non-treated strain PSB-S cells and quantified (Fig. 4). The result indicated that the accumulation of carotenoid in the pyrazosulfuron-ethyl-treated cells was significantly inhibited by about $23.04 \%$ compared with the control cells. The biosynthesis of bacteriochlorin in the pyrazosulfuron-ethyl-treated cells was, however, not affected significantly by the pyrazosulfuron-ethyl treatment. Although the total photo-pigments biosynthesis in the pyrazosulfuron-ethyl-treated cells was inhibited significantly, this inhibition was likely caused by the reduction of carotenoid biosynthesis.

\section{2-DE gel and mass spectrometry of protein patterns from R. palustris PSB-S cells}

To reveal the protein expression changes in $R$. palustris PSB-S cells under pyrazosulfuron-ethyl stress, we extracted total protein from $R$. palustris PSB-S cells treated with $50 \mu \mathrm{g} / \mathrm{mL}$ pyrazosulfuron or non-treated control cells for proteome profile analyses by 2-DE. Protein extracts from three independent biological samples per treatment were visualized individually in three technical replicate gels for comparison. About 1127 detectable protein spots were counted in each gel after Coomassie Brilliant Blue staining (Fig. 5). The three sets of independent biological samples ensured that the changes of protein abundance in cells were reproducible and thus reliable. Analyses of the gel images showed that over 246 protein spots were altered significantly in their expression according to the $t$-test $(t<0.05)$. Of these identified 

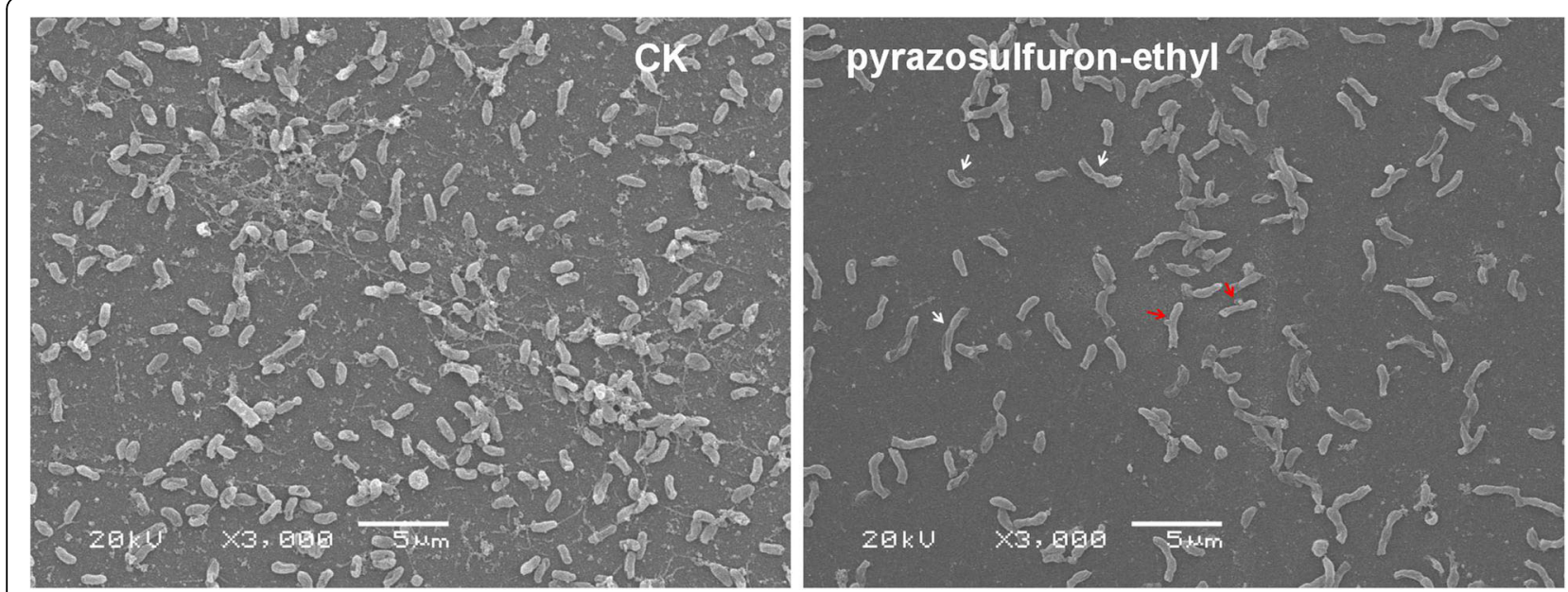

Fig. 2 Effect of pyraxosulfuron-ethyl on R. palustris PSB-S cell morphology. (a) CK; (b) pyraxosulfuron-ethyl. The cells were harvested at 7 days post culturing and examined by Scanning Electron Microscopy. R. palustris PSB-S cells showing curving or budding are indicated with white and red arrows, respectively. $\mathrm{Bar}=5 \mu \mathrm{m}$

protein spots, 102 spots were suitable for further analyses by Mass Spectrometry. After mass spectrometry, the protein spots were annotated using the Uniprot Knowledgebase (www.uniprot.org) or the NCBI (www.ncbi.nlm.nih.gov) database with BLASTP. Identities of 56 protein spots were successfully identified while the other 46 protein spots remained unidentified mainly due to their lower total ion score [C.I.; $<95 \%$ (data not shown)].

Twenty six up- and thirty down-regulated proteins in $R$. palustris PSB-S cells are shown in Additional file 1: Table S1. The protein displaying the highest up-regulation was elongation factor G (gi|169,830,041; + 24.83 fold; protein spot number 1703), followed by a cell division associated protein FtsZ (gi|115,524,129; + 7.49 fold; protein spot 1604) and the ATP synthase subunit alpha (gi|169,826,598; + 3.49 fold; protein spot 3507). The protein showing the strongest down-regulation was a periplasmic component of an ABC-type branched-chain amino acid transport complex (gi|115,525,850; - 0.07 fold; protein spot 7310 ) followed by a protein with unknown function (hypothetical protein MT1820.1; gi|15,841,238; -0.13 fold; protein spot 6621).

Ten differential expressed proteins, including five up-regulated and five down-regulated proteins, were selected for validation analyses through quantitative RT-PCR (qRT-PCR) using specific primers (Additional file 1: Table S2). Results of the analyses indicated that

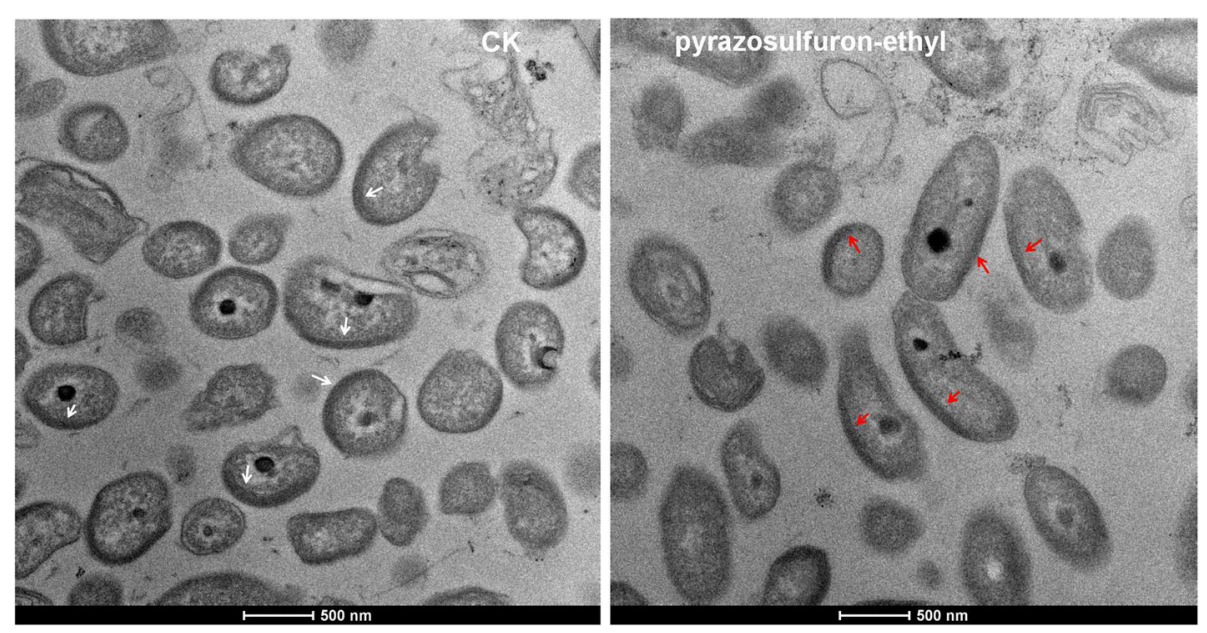

Fig. 3 Internal changes in R. palustris PSB-S cells treated with pyraxosulfuron-ethyl. (a) CK; (b) pyrazosulfuron-ethyl. R. palustris PSB-S cells were fixed and embedded in the resin. Thin sections of the cells were examined for internal changes by TEM. Electron dense areas in the cells are indicated with arrows 


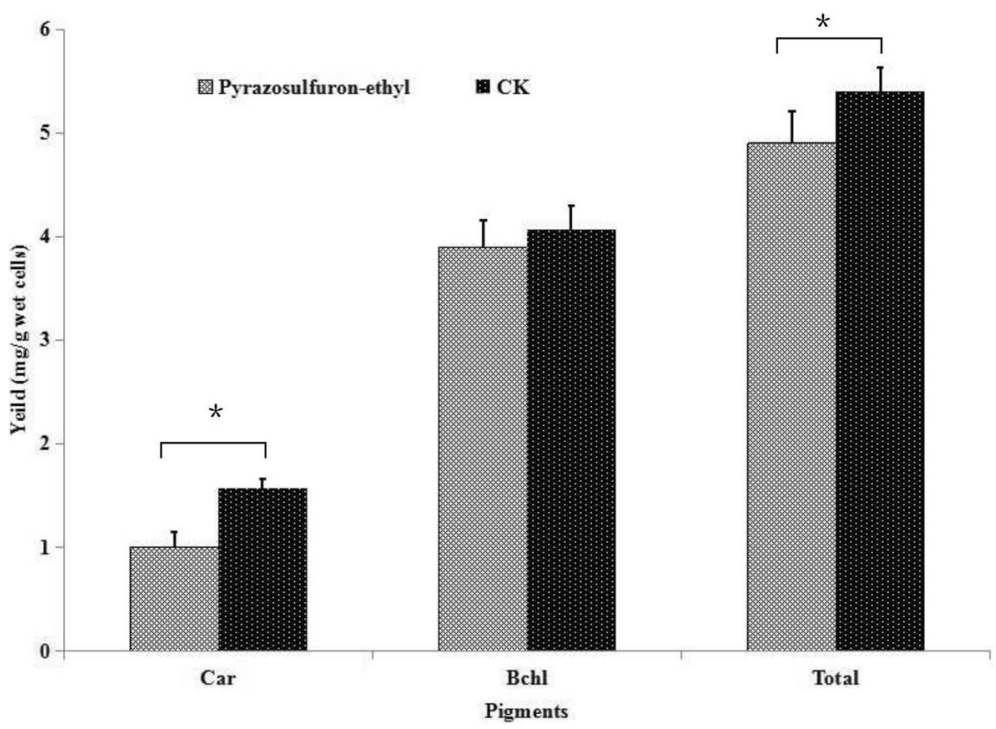

Fig. 4 Effect of pyraxosulfuron-ethyl treatment on photo-pigments biosynthesis. Accumulation of carotenoid and bacteriochlorin in the pyraxosulfuronethyl treated (pyraxosulfuron-ethyl) or non-treated control (CK) PSB-S cells was measured using a modified methanol/acetone extraction method. Each treatment had three biological replicates. *, $p<0.05$. Car, Carotenoid accumulation; Bchl, Bacteriochlorin accumulation; Total, total amount of Carotenoid and Bacteriochlorin

the transcriptional levels of the selected genes agreed with the protein expression profiles determined by the proteomic analyses (Additional file 1: Figure S1).

The identified differentially expressed proteins were used to determine the enriched GO categories, including biological processes, molecular functions and cellular localizations. The main enriched categories for the up- and down-regulated proteins are shown in Additional file 1: Fig. S2. The three major groups in the biological processes category contained proteins involved in biological processes, small molecule metabolic processes and biosynthetic processes (Additional file 1: Figure S2A). The four main groups in the cellular localization category were proteins related to cellular component,

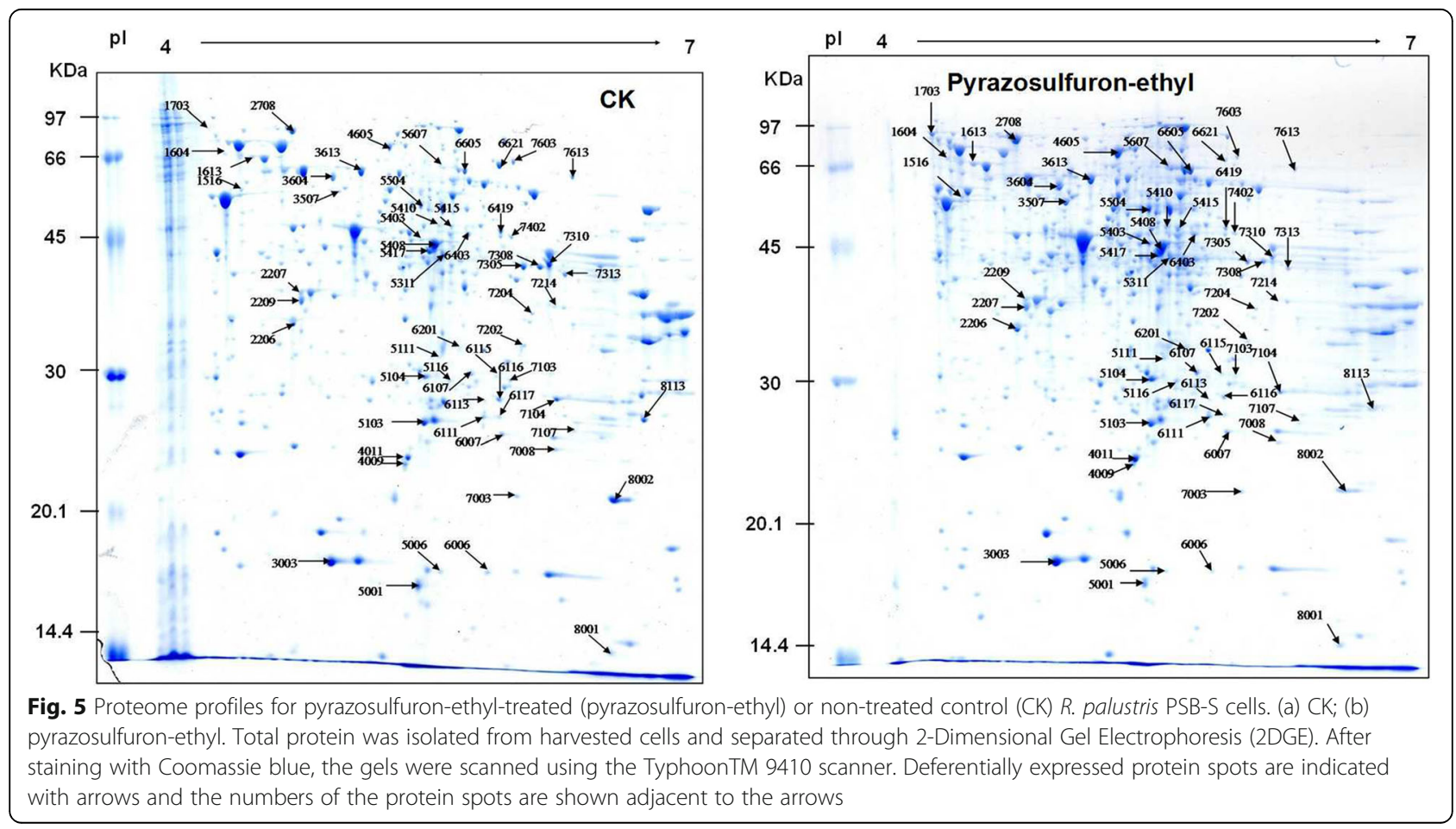


cell, cytoplasm, and intracellular (Additional file 1: Figure S2B). For the molecular function category, most up-regulated proteins were grouped in the molecular function, ion binding, transferase activity, and oxidoreductase activity groups. The down-regulated proteins were, however, grouped in the molecular function, ion binding, and ATPase activity groups respectively (Additional file 1: Figure S2C).

In addition to GO, protein-protein interaction networks were also predicted in this study using STRING Database (http://string-db.org/, version 10.0). As shown in Fig. 6, the deferentially expressed proteins were mainly enriched in the term synthesis and degradation of ketone bodies (RPA4156) and was connected to electron-transfer-flavoprotein (etfA) based on protein homology. Term cysteine and methionine metabolism (RPE_4204) was connected to malate dehydrogenase (mdh) based on protein homology and term cell division (RPE_2116) was linked to gene co-occurance. Term cellular component organization (RPE_2116) was connected to transcription elongation (nusG) as gene co-occurrance.

RPA4156, etfA and their connected proteins are involved in energy generation and homeostasis. These proteins may affect bacterial cell survival. RPE_4204 and $\mathrm{mdh}$, and RPE_2116 and its interacted proteins are known to participate in proteins synthesis and multiplication. These proteins may be crucial for bacterial cells propagation. RPE_2116, nusG and their interacted proteins are known to be responsible for protein translation, biosynthesis and cell structure. These protein may affect bacterium cell morphology.

\section{Discussion}

Effect of pyrazosulfuron-ethyl on R. palustris PSB-S cell cytological changes

Pyrazosulfuron-ethyl was reported to inhibit the activities of cellulolytic, proteolytic and phosphate solubilizing enzymes in soil bacteria [20]. In this study, the cytological changes in $R$. palustris PSB-S cells treated with pyrazosulfuron-ethyl included decrease of biomass and cell size (Fig. 2). These changes may correlate with the 7.49-fold up-regulation of cell division protein FtsZ (protein spot 1604) in the pyrazosulfuron-ethyl-treated cells. It was previously reported that FtsZ protein could regulate the initial peptidoglycan synthesis, inhibit cell division during the onset of cytokinesis, and increase the length of bacterial and archaea cells [32]. Flagella biosynthesis was reported to be controlled by fla genes and the cognate CheY protein [33]. In the current study, the expressions of fla proteins and the CheY protein were apparently not affected by pyrazosulfuron-ethyl treatment according to the 2-DE gel analyses (Fig. 5, Additional file 1: Table S1). We speculate that the loss of polar flagella formation on the pyrazosulfuron-ethyl-treated cells was caused by a significant reduction of biomass production in the pyrazosulfuron-ethyl-treated cells. It is also possible that of our 2-DE gel analyses were not sensitive enough to detect the changes of these proteins as previously described [34].

R. palustris can proliferate through two major developmental processes (i.e., binary fission under oxygen limitation and illumination conditions or budding) [35]. Because pyrazosulfuron-ethyl treatment could induce $R$. palustris PSB-S cells to bud under the oxygen limitation

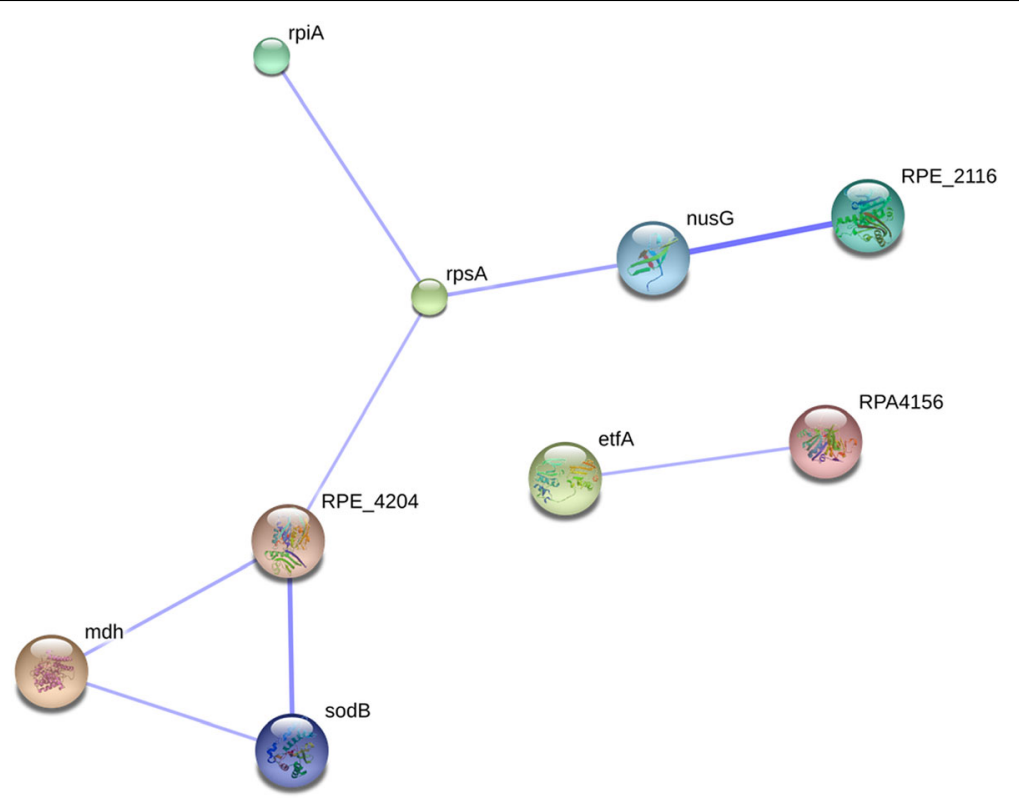

Fig. 6 Protein-protein interaction networks predicted for differentially expressed proteins using STRING Database version 10.0 
and illumination conditions, it is possible that the stresses caused by pyrazosulfuron-ethyl treatment perturbed the development of PSB-S cells. The reason why $R$. palustris PSB-S can tolerate pyrazosulfuron-ethyl treatment might be interpreted as the bacteria has evolved both proliferation strategies mentioned above to counteract the toxicity of pyrazosulfuron-ethyl.

\section{Photopigment biosynthesis and photosynthetic rate}

Rhodopseudomonas bacteria are purple nonsulfur phototrophic organisms with unique abilities to use light as its energy source for photosynthesis. The photosynthetic reaction complexes of Rhodopseudomonas bacteria contain two photopigments (bacteriochlorin $\mathrm{b}$ and carotenoid) that can convert carbon dioxide to cell mass [36]. Results obtained in this study showed that pyrazosulfuron-ethyl could significantly inhibit the biosynthesis of carotenoid (Figs. 3 and 4), leading to a decrease in light aggregation capacity [37]. As a compensation, the photosynthetic rate in pyrazosulfuron-ethyl-treated $R$. palustris PSB-S cells was up-regulated (protein spot 3507) (Additional file 1: Table S1, KO00195, http://www.genome.jp/kegg-bin/ show_pathway?ko00195). This increased photosynthetic rate may be considered as a strategy used by $R$. palustris PSB-S cells to counteract the reduction of light aggregation. This strategy may serve as a crucial defense mechanism in R. palustris PSB-S cells against pyrazosulfuron-ethyl toxicity.

\section{Cell homeostasis}

Maintenance of a relatively constant internal cytosol concentrations under different environmental stresses is essential for most organisms to survive [38]. Pyrazosulfuron-ethyl is known to be hydrophobic [39]. This character may allow it to permeate into cells and change the homeostasis of $R$. palustris PSB-S cells. To counteract the perturbation, $R$. palustris PSB-S cells down-regulated the expressions of proteins belonging to the ABS transporter family (i.e., protein spot 5001, 8113, 6115, 7308, 7313, 7103 and 7310; Additional file 1: Table S1) upon pyrazosulfuron-ethyl treatment. The down-regulation of these ABS transporter family protein expressions might resulted in limitation of pyrazosulfuron-ethyl penetration into cytoplasm through cell membrane [40]. Prevention or limitation of pyrazosulfuron-ethyl penetration into cell may be crucial for $R$. palustris PSB-S to survive under the pyrazosulfuron-ethyl stress.

\section{Pyrazosulfuron-ethyl inactive target proteins}

The active mechanism of herbicides in the sulfonylurea family to kill weeds is to inhibit the catalytic activity of acetolactate synthase (ALS), rather than to inhibit the biosynthesis of ALS [41]. This active mechanism may not apply to the results obtained in this study because our qRT-PCR (Additional file 1: Fig. S1) and proteome (Additional file 1: Table S1) analyses demonstrated that the expression of ALS 3 catalytic subunit (protein spot 7613) and ALS 3 regulatory subunit (protein spot 8002), the large and small subunit of ALS 3 protein complex, were significantly down-regulated.

Plants harboring mutant acetolactate synthase (ALS) genes were shown to be resistant to sulfonylurea herbicides [42-44]. It was also reported that although the activities of Salmonella typhimurium ALS II/ALS III or Escherichai coli ALS III could be inhibited by sulfometuron-methyl, their ALS I was insensitive to sulfometuron methyl $[41,45]$. Like E. coli, R. palustris ALS I and ALS III are encoded by $i l v B$ and $i l v H I$, respectively, while the missed ALS II is encoded by ilvG [46, 47]. In this study, the expression of both ALS III subunits were suppressed by pyrazosulfuron-ethyl treatment while the expression of ALS I protein remained unchanged. This finding may explain why $R$. palustris PSB-S is resistant to pyrazosulfuron-ethyl application in field.

In bacteria, the function of ALS is known to involve isoleucine and valine biosynthesis [48]. It is possible that down-regulation of ALS III protein expression in pyrazosulfuron-ethyl-treated cells resulted in an down-regulation of proteins involved in cysteine and methionine metabolism (i.e., RPE_4204). In addition, the expressions of malate dehydrogenase $(\mathrm{mdh})$ and proteins important in cell division (RPE_2116) pathway were also modulated (Fig. 6). ALS was also reported to play a distinct role in sodium-ion homeostasis in plant cells, plant patterning and development [49] as well as isobutanol biosynthesis [50], important for bacteria resistance to environmental stress [51]. Consequently, we speculate that ALS III is a crucial enzyme in metabolic pathway controlling $R$. palustris PSB-S adaption to pyrazosulfuron-ethyl stress.

\section{Proteins with unknown functions}

Five down-regulated proteins were annotated as proteins with unknown functions (protein spot 5006, 6107, 7104 and 7107) or hypothetical protein MT1820.1 (protein spot 6621). Protein spot 5006 sheared partial sequence homology with hypothetical protein blr5132 [52] which was shown to have a conserved domain similar in structure to chorismate mutase important in synthesizing essential amino acids, phenylalanine and tyrosine in bacteria [53, 54]. Protein spot 6107 sheared a conserved domain with enoyl-[acyl-carrier-protein] reductase of Mycobacterium tuberculosis [55], a key enzyme in the type II fatty acid synthesis system. Protein spot 7104 sheared sequence homology with 3-oxoacid CoA-transferase subunit A of Rhodopseudomonas palustris [36] known to be crucial in energy generation [56]. Protein spot 7107 sheared sequence homology with DNA-binding response regulator. It was reported that suppression of this regulator abolished 
bacteria growth under phosphate limitation conditions [57]. Down-regulation of these four protein expressions in the pyrazosulfuron-ethyl-treated PSB-S cells might result in inhibition of biosynthesis of essential amino acids and fatty acid, and energy generation leading to a reduction of biomass production in PSB-S cells (Fig. 1). The hypothetical protein MT1820.1 (protein spot 6621) has no known conserved domain. Its cellular localization and biological function also remain obscure. Whether down-regulation of this protein can affect PSB-S cell growth under the pyrazosulfuron-ethyl stress requires further investigation.

\section{Conclusion}

Results presented in this paper showed pyrazosulfuron-ethyl treatment caused significant changes in morphology and photopigment biosynthesis in $R$. palustris PSB-S cells. Changes in proteomic profile in the pyrazosulfuron-ethyl stressed $R$. palustris PSB-S cells are also presented. The up-regulated proteins are mainly involved in transcription, stress response, or small molecule metabolism. Up-regulation of protein expressions, including elongation factor G, cell division FtsZ, and, ATP synthase, and superoxide dismutase, as well as down-regulation of protein expressions, including ALS III and ABC transporters, and other proteins with unkown functions may play roles in $R$. palustris PSB-S survival and adaptation to pyrazosulfuron ethyl stresses. Further functional studies are needed to elucidate the functions of these proteins in bacteria adaption to stresses. The proteins identified through these studies should benefit the generations of transgenic crops resistant to the toxicities of herbicides beloning to the sulphonylurea family.

\section{Additional file}

Additional file 1: Figure S1. Comparison of results obtained through protein expression analysis (blue bars) or qRT-PCR (red bars). The height of the bars indicate the fold changes. Identification numbers of the analyzed proteins are indicated. Figure S2. Gene ontology (Go) enrichment of the identified up- or down-regulated proteins in $R$. palustris PSB$S$ cells treated with $50 \mu \mathrm{g} / \mathrm{ml}$ pyrazosulfuron-ethyl. A protein was considered to be differentially expressed in the pyrazosulfuron-ethyl-treated $R$. palustris PSB-S cells if $t<0.05$. The GO enrichment analyses were performed using Blast2GO. (A) Number of proteins belonging to various groups in the biological process category. (B) Number of proteins belonging to various groups in the molecular function category. (C) Number of proteins belonging to various groups in the cellular localization category. Table S1. Differentially expressed proteins during R.palustris PSB-S treated with 50 mg/L pyrazosulfuron. Table S2. Primers for qRT-PCR. (PDF 293 kb)

\section{Abbreviations}

2-DE: 2-dimensional gel electrophoresis; ALS: acetolactate synthase; Bchl: bacteriochlorin; Car: barotenoid; DPS: data processing system; etfA: electron-transfer-flavoprotein A; GO: gene orthology; KEGG: Kyoto Encyclopedia of Genes and Genomes; MALDI-TOF/TOF-MS: matrix-assisted laser desorption /ionization tandem time-of-flight mass spectrometry; mdh: malate dehydrogenase; RubisCO: ribulose 1,5-bisphosphate carboxylase/oxygenase; SD: standard deviation; TEM: transmission electron microscopy

\section{Acknowledgements}

I would like to thank Jian Yang for technical assisstance of genes GO analysis.

\section{Funding}

This work was financially supported by the National Key R\&D Program of China (2017YFD0800702), the National Natural Science Foundation of China (grants 3140110978 ), the Agriculture Research System of China (CARS-23-D02), and Hunan Talent Project (2016RS2019). The funders had no contribution on study design, data analysis, decision to publish, or preparation of the manuscript.

\section{Availability of data and materials}

All data generated or analyzed during this study are included in this published article and its supplementary information files.

\section{Authors' contributions}

SBZ, DYZ, YL designed the study; XWL, THZ performed the experiments; SBZ, $J P$ analyzed the data; $S B Z, X G Z$ and $Y L$ wrote the manuscript. All authors discussed the results on the manuscript. All authors read and approved the final manuscript.

Ethics approval and consent to participate

Not applicable.

\section{Consent for publication \\ Not applicable.}

\section{Competing interests}

The authors have declared that no competing interest exists.

\section{Publisher's Note}

Springer Nature remains neutral with regard to jurisdictional claims in published maps and institutional affiliations.

\section{Author details}

${ }^{1}$ Key laboratory of pest management of horticultural crop of Hunan province, Hunan Plant Protection Institute, Hunan Academy of Agricultural Science, No 726 Second Yuanda Road, Furong District, Changsha 410125, Hunan province, People's Republic of China. ${ }^{2}$ Plant Protection College, Hunan Agricultural University, Changsha 410128, China. ${ }^{3}$ Department of Entomology, University of Kentucky, Lexington, KY 40546, USA.

Received: 14 July 2018 Accepted: 29 November 2018 Published online: 07 December 2018

References

1. Pang SS, Guddat LW, Duggleby RG. Molecular basis of sulfonylurea herbicide inhibition of acetohydroxyacid synthase. J Biol Chem. 2003;278: 7639-44.

2. Mei Y, Liu M, Qiu L, et al. Investigation of resistance levels and mechanisms to nicosulfuron conferred by non-target-site mechanisms in large crabgrass (Digitaria sanguinalis L.) from China. Pestic Biochem Physiol. 2017;141:84-9.

3. Pan D, Li QX, Lin Z, et al. Interactions between salicylic acid and antioxidant enzymes tilting the balance of $\mathrm{H} 2 \mathrm{O} 2$ from photorespiration in non-target crops under halosulfuron-methyl stress. Pestic Biochem Physiol. 2017;143: 214-23.

4. Blair AM, Martin TD. A review of the activity, fate and mode of action of sulfonylurea herbicides. Pestic Sci. 1988:22:195-219.

5. Soltan N, Sikkem PH, Robinson DE. Vegetable crop responses to chlorimuron-ethyl applied in the previous year. Crop Prot. 2005;24:685-8.

6. II-Bin I, Usui K. Factors and recovery of herbicide phytotoxicity on directseeded rice variation factors of phytotoxicity. Kor J Weed Sci. 1996;16:292300.

7. Latha PC, Gopal H. Influence of herbicides on cellulolytic, proteolytic and phosphate solubilising bacteria. Int J Plant Protect. 2010;3:83-8.

8. Breteton MF, Iberl M, Shimomura K, et al. Reversible changes in pancreatic islet structure and function produced by elevated blood glucose. Nat Commun. 2014;5:4639.

9. Remedi MS, Nichols CG. Chronic antidiabetic sulfonylureas in vivo: reversible effects on mouse pancreatic $\beta$-cells. PLoS Med. 2008;5:e206. 
10. Zhao $L$, Jing $X$, Chen $L$, et al. Tribenuron-methyl induces male sterility through anther-specific inhibition of acetolactate synthase leading to autophagic cell death. Mol Plant. 2015;8:1710-24.

11. Li Z, Cheng Y, Cui J, et al. Comparative transcriptome analysis reveals carbohydrate and lipid metabolism blocks in Brassica napus L. male sterility induced by the chemical hybridization agent monosulfuron ester sodium. BMC Genomics. 2015;16:206.

12. Gibson B, Vidgren V, Peddinti G, et al. Diacetyl control during brewery fermentation via adaptive laboratory engineering of the lager yeast Saccharomyces pastorianus. J Ind Mcirobiol Biotechnol. 2018:1-10.

13. Iwakami S, Watanabe H, Miura T, et al. Occurence of sulfonylurea resistance in Sagittaria trifolia, a basal monocot species, based on target-site and nontarget-site resistance. Weed Biol Manag. 2014;14:43-9.

14. Das M, Reichman JR, Haberer $G$, et al. A composite transcriptional signature differentiates responses towards closely related herbicides in Arabidopsis thaliana and Brassica napus. Plant Mol Biol. 2010;72:545-56.

15. Menegat A, Bailly GC, Aponte R, et al. Acetohydroxyacid synthase (AHAS) amino acid substitution Asp376Glu in Lolium perenne: effect on herbicide efficacy and plant growth. J Plant Dis Prot. 2016;123:145-53.

16. Yao X, Wang YQ, Yue XP, et al. Generation of tribenuron-methyl herbicideresistant OsCYP81A6-expressing rapeseed (Brassica napus L.) plants for hybrid seed production using chemical-induced male sterility. Plant Breed. 2016;135:349-54.

17. Yu Q, Han HP, Vila-Aiub MM, et al. AHAS herbicide resistance endowing mutations: effect on AHAS functionality and plant growth. J Exp Bot. 2010; 61:3925-34.

18. Agapito-Tenfen SZ, Vilperte $\mathrm{V}$, Benevenuto RF, et al. Effect of stacking insecticidal cry and herbicide tolerance epsps transgenes on transgenic maize proteome. BMC Plant Biol. 2014;14:346.

19. Fang $Y Z$, Lu HP, Chen $S$, et al. Leaf proteome analysis provides insights into the molecular mechanisms of bentazon detoxification in rice. Pesti Biochem Physiol. 2015;125:45-52.

20. Latha PC, Gopal H. Effect of herbicides on soil microorganisms. Ind J Weed Sci. 2010;42:217-22.

21. Ritchie RJ. The use of solar radiation by the photosynthetic bacterium, Rhodopseudomonas palustris: model simulation of conditions found in a shallow pond or a flatbed reactor. Photochem Photobiol. 2013:89:1143-62.

22. Yin LB, Liu Y, Zhang DY, et al. Isolation and characterization of Rhodopseudomonas sp. S9-1 capable of degrading pyrazosulfuron-ethyl. Adv Mater Res. 2012;356-360:1152-63.

23. Du J. 2015. The adaption mechanisms of Rhodopseudomonas palustris PSB-S against pyrazosulfuron-ethyl stress. http://kns.cnki.net/KCMS/detail/detail. aspx?dbcode $=$ CMFD\&dbname $=$ CMFD201701\&filename $=1016153152 . \mathrm{nh} \& \mathrm{v}=$ MDU5MzdydkxWRjl2ROxLOUhkREpyWkViUEISOGVYMUx1eFITNORoMVQzcVRy V00xRnJDWJMMmZZdWRwRnkva1c=.

24. Akiba T, Usami R, Horikoshi K. Rhodopseudomonas rutile, a new species of nonsulfur purple photosynthetic bacteria. Int J Syst Bacteriol. 1983;33:551-6.

25. Mehrabi S, Ekanemesang UM, Aikhionbare FO, et al. Identification and characterization of Rhodopseudomonas spp., a purple, non-sulfur bacterium from microbial mats. Biomol Eng. 2001;18:49-56.

26. Zhou MQ, Zhao C, Cheng Q. Yet al. Fingerprinting analysis of photopigments in purple bacteria. Acta Microbiol Sin. 2012;52:760-8.

27. Bradford MM. A rapid and sensitive for the quantitation of microgram quantitites of protein utilizing the principle of protein-dye binding. Anal Biochem. 1976;72:248-54.

28. Blackshear PJ. Systems for polyacrylamide gel electrophoresis. Methods Enzymol. 1984;104:237-55.

29. Wang XC, Chang L, Wang B. Wet al. Comparative proteomics of Thellungiella halophila leaves from plants subjected to salinity reveals the importance of chloroplastic starch and soluble sugars in halophyte salt tolerance. Mol Cell Proteomics. 2013;12:2174-95.

30. Conesa A, Götz S. Blast2GO: a comprehensive suite for functional analysis in plant genomics. Int J Plant Genom. 2008;619832.

31. Tang QY, Zhang CX. Data processing system (DPS) software with experimental design, statistical analysis and data mining developed for use in entomological research. Insect Sci. 2013;20:254-60.

32. Yao Q, Jewett Al, Chang Y, et al. Short FtsZ filaments can drive asymmetric cell envelope constriction at the onset of bacterial cytokinesis. The EMBO J. 2017;36:959-1116.
33. Hernandez-Valle J, Domenzain C, de la Mora J, et al. The master regulators of the Fla1 and Fla2 flagella ofRhodobacter sphaeroides control the expression of their cognate CheY proteins. J Bacteriol. 2017;199:e00671-16.

34. Chang IF, Curran A, Harper J. Proteomic profiling of tandem affinity pruified 14-3-3 protien complexes in Arabidopsis thaliana. Proteomics. 2009;9:2967-82.

35. Angert ER. Alternatives to binary fission in bacteria. Nat Rev Microbiol. 2005; 3:214-24.

36. Larimer FW, Chain P, Hauser L, et al. Complete genome sequence of the metabolically versatile photosynthetic bacterium Rhodopseudomonas palustris. Nat Biotechnol. 2004;22:55-61.

37. Zhao C, Yue HY, Cheng QR, et al. What caused the formation of the absorption maximum at $421 \mathrm{~nm}$ in vivo spectra of Rhodopseudomonas palustris. Photochem Phtobiol. 2014;90:1287-92.

38. Savir Y, Martynov A, Springer M. Achieving global perfect homeostasis through transporter regulation. PLoS Comput Biol. 2017;13:e1005458.

39. Zheng M, Yates SR, Papiernik SK. Transformation kinetics and mechanis of the sulfonylurea herbicides pyrazosulfuron ethyl and halosulfuron methyl in aqueous solutions. J Agric Food Chem. 2008;56:7367-72.

40. Hediger MA, Clemencon B, Burrier RE, et al. The ABCs of membrane transporters in health and disease (SLC series): introduction. Mol Asp Med. 2013;34:95-107.

41. LaRossa RA, Schloss JV. The sulfonylurea herbicide sulfometuron methyl is an extremely potent and selective inhibitor of acetolactate synthase in Salmonella typhimurium. J Biol Chem. 1984;259:8753-7.

42. Brosnan JT, Vargas JJ, Breeden GK, et al. A new amino acid substitution (ala205-Phe) in acetolactate synthase (ALS) confers broad spectrum resistance to ALS-inhibiting herbicides. Planta. 2016;243:149-59.

43. Gardin CJA, Gouzy J, Carrere S, et al. ALOMY base, a resource to investigate non-target-site-based resistance to herbicides inhibiting acetolactatesynthase (ALS) in the major grass weed Alopecurus myosuroides (blackgrass). BMC Genomics. 2015;16:590.

44. Walter $\mathrm{KL}$, Strachan SD, Ferry NM, et al. Molecular and phenotypic characterization of Als1 and Als2 mutations conferring tolerance to acetolactate synthase herbicides in soybean. Pest Manag Sci. 2014;70: 1831-9.

45. LaRossa RA, Smulski DR. ilvB-encoded acetolactate synthase is resistant to the herbicide sulfometuron methyl. J Bacteriol. 1984;160:391-4.

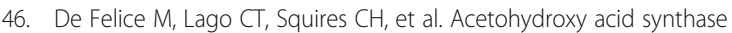
isoenzymes of Escherichia coli K-12 and Salmonella typhimurium. Ann Microbiol (Paris). 1982;133A:251-6.

47. Pechter KB, Gallagher L, Pyles $H$, et al. Essential genome of the metabolically versatile alphaproteobacterium Rhodopseudomonas palustris. J Bacteriol. 2016;198:867-76.

48. Dailey FE, Cronan JE. Acetohydroxy acid synthase I, a required enzyme for isoleucine and valine biosynthesis in Escherichia coli K-12 during growth on acetate as the sole carbon source. J Bacteriol. 1986;165:453-60.

49. Mohammad H, Foreman C, Jalili E, et al. Acetolactate synthase regulatory subunits play divergent and overlapping roles in branchedchain amino acid synthesis and Arabidopsis development. BMC Plant Biol. 2017;17:71

50. Sommer B, Moeller HV, Haack M, et al. Detailed structure-function correlations of Bacillus subtilis acetolactate synthase. Chembiochem. 2015;16: $110-8$.

51. Lin PP, Rabe KS, Takasumi JL, et al. Isobutanol production at elevated temperatures in thermophilic Geobacillus thermoglucosidasius. Metab Eng. 2014:24:1-8

52. Kaneko T, Nakamura Y, Sato $\mathrm{S}$, et al. Complete genomic sequence of nitrogen-fixing symbiotic bacterium Bradyrhizobium japonicum USDA110. DNA Res. 2002;9:225-56.

53. Frederik C, Ranaghan KE, Macrae SJ, et al. Analysis of chorismate mutase catalysis by QM/MM modeling of enzyme-catalysed and uncatalysed reactions. Org Biomol Chem. 2011;9:1578-90.

54. Khanapur M, Alvala M, Prabhakar M, et al. Mycobacterium tuberculosis chorismate mutase: a potential target for TB. Bioorg Med Chem. 2017;25: 1725-36.

55. Fleischmann RD, Alland D, Eisen JA, et al. Whole-genome comparison of Mycobacterium tuberculosis clinical and laboratory strains. J Bacteriol. 2002; 184:5479-90. 
56. Korolev S, Koroleva O, Petterson K. Get al. Autotracing of Escherichia coli acetate CoA-transferase a-subunit structure using $3.4 \AA \mathrm{MAD}$ and $1.9 \AA$ native data. Acta Crystallogr D Biol Crystallogr. 2002;58:2116-21.

57. James JN, Hasan ZN, loerger TR, et al. Deletion of SenX3-RegX3, a key twocomponent regulatory system of Mycobacterium smegmatis, results in growth defects under phosphate-limiting conditions. Microbiol. 2012;158: 2724-31.

Ready to submit your research? Choose BMC and benefit from:

- fast, convenient online submission

- thorough peer review by experienced researchers in your field

- rapid publication on acceptance

- support for research data, including large and complex data types

- gold Open Access which fosters wider collaboration and increased citations

- maximum visibility for your research: over $100 \mathrm{M}$ website views per year

At $B M C$, research is always in progress.

Learn more biomedcentral.com/submissions 